\title{
ВОПРОСЫ ОБУЧЕНИЯ ИНОЯЗЫЧНОМУ АУДИРОВАНИЮ СТУДЕНТОВ СРЕДНЕГО ПРОФЕССИОНАЛЬНОГО ОБРАЗОВАНИЯ
}

\author{
O. C. Xamзunempy \\ Московский колледж управления гостиничного бизнеса \\ информационных технологий «Царицыно»
}

\begin{abstract}
Аннотация: В статье раскрываются вопросы связанные с процессом аудирования студентов среднего профессионального образования.
\end{abstract}

Ключевые слова: иностранный язык; иноязычное аудирование; среднее профессиональное образование

\section{ISSUES OF TRAINING COLLEGE STUDENTS IN FOREIGN- LANGUAGE LISTENING COMPREHENSION SKILLS}

\author{
O. S. Khatzipetru \\ Moscow College of Administration, \\ Hotel Business and Information Technologies "Tsaritsyno"
}

Abstract: The paper reveals issues connected with the process of training college students in listening comprehension skills.

Keywords: foreign language; foreign-language listening comprehension skills; college education

За последние десятилетия произошли важные изменения, связанные с обновлением содержания отечественного образования в целом, и среднего профессионального образования в частности. Изменения в первую очередь направлены на повышение качества российского профессионального образования и его интеграцию в международное образовательное пространство, увеличение гибкости образовательных программ, а также внедрение новых федеральных государственных образовательных стандартов среднего профессионального образования.

В Федеральном законе «Об образовании в Российской Федерации» подчеркивается следующее: «Среднее профессиональное образование направлено на решение задач интеллектуального, культурного и профессионального развития человека и имеет целью подготовку квалифицированных рабочих или служащих и специалистов среднего звена по всем основным направлениям общественно полезной деятельности в соответствии с потребностями общества и государства» (Федеральный закон ... , Электр. ресурс). 
Исходя из анализа текста Государственной программы Российской Федерации «Развитие образования» на 2013-2020 годы, можно отметить, что в качестве основной задачи, выдвигаемой для системы профессионального образования, является формирование у студентов не только профессиональных, но и базовых социальных и культурных компетенций. Также в данной программе прописана задача по интернационализации российского образования и расширения экспорта российских образовательных услуг. Для ее решения необходимо реализовать меры по существенному расширению международной академической мобильности российских преподавателей и студентов. Кроме того, в программе отмечается необходимость разработки и внедрения образовательных программ на иностранных языках и обеспечения поддержки проектов, направленных на обновление преподавания иностранного языка. Согласно данному документу в процессе обучения иностранному языку необходимо уделять больше внимания устному общению творчески развитой личности, которая будет решать профессионально и жизненно значимые проблемы (Постановление Правительства РФ от 15 апреля ..., Электр. ресурс). Особенно данное требование актуально для сферы туризма, где знание иностранного языка, является важной составляющей успешного ведения бизнеса.

Рассмотрим требования, которые предъявляются в отношении специальности 43.02.10 - «туризм». В соответствии с приказом Министерства образования и науки РФ от 7 мая 2014 г. № 474 «Об утверждении федерального государственного образовательного стандарта среднего профессионального образования по специальности 43.02.10 Туризм» в пункте 6.3 отмечается, что в обязательной части общего гуманитарного и социально-экономического учебного цикла программ подготовки специалистов среднего звена (ППССЗ) базовой подготовки должна предусматривать изучение такой обязательной дисциплины как «Иностранный язык». В процессе освоения общего гуманитарного и социально-экономического цикла (ОГСЭ.03) «Иностранный язык» у обучающегося формируются и развиваются такие общекультурные компетенции (OK), как:

- ОК 1 - понимать сущность и социальную значимость своей будущей профессии, проявлять к ней устойчивый интерес;

- ОК 2 - организовывать собственную деятельность, определять методы и способы выполнения профессиональных задач, оценивать их эффективность и качество;

- ОК 3 - решать проблемы, оценивать риски и принимать решения в нестандартных ситуациях;

- ОК 4 - осуществлять поиск, анализ и оценку информации, необходимой для постановки и решения профессиональных задач, профессионального и личностного развития; 
- ОК 5 - использовать информационно-коммуникационные технологии для совершенствования профессиональной деятельности;

- ОК 6 - работать в коллективе и команде, обеспечивать ее сплочение, эффективно общаться с коллегами, руководством, потребителями;

- ОК 7 - ставить цели, мотивировать деятельность подчиненных, организовывать и контролировать их работу с принятием на себя ответственности за результат выполнения заданий;

- ОК 8 - самостоятельно определять задачи профессионального и личностного развития, заниматься самообразованием, осознанно планировать повышение квалификации;

- ОК 9 - быть готовым к смене технологий в профессиональной деятельности (Приказ Министерства ..., Электр. ресурс).

Наиболее эффективным методом для реализации данных компетенций является аудирование, которое за последние годы все больше привлекает внимание ученых. Такое пристальное внимание исследователей к методу аудирования связано тем, что приоритетным направлением преподавания иностранного является обучение пониманию и восприятию речи на слух.

Изучением вопросов обучения аудированию занимались зарубежные (Brown, 1988; Richards, 2008; Бриггс, 2017; Harmer, 2001; White, 1998) и отечественные ученые (Жинкин, 1982; Зимняя, 2001; Ильина, 1969; Кочкина, 1964 и др.). Рассмотрением практических аспектов обучения иноязычному аудированию занимались такие ученые, как Н. Д. Гальскова (Гальскова, 2004), Н. И. Гез (Гез, 2004), Н. В. Елухина (Елухина, 1996), И.А.Зимняя (Зимняя, 2001), В. И. Ильина (Ильина, 1969), Е. Н. Соловова (Соловова, 2003), И.И. Халеева (Халеева, 1989) и др.

Данный вид речевой деятельности, как отмечали перечисленные выше исследователи в процессе исследования вопросов целенаправленного обучения аудированию, имеет определенные особенности, которые обуславливают специфику обучения аудированию и относят его к одному из самых трудных.

Рассматривая аудирование как один из видов речевой деятельности И. А. Зимняя понимает его как «сложную перцептивно-мыслительномнемическую внутреннюю деятельность человека» (Зимняя, 2001: 117). Как отмечает ученая, мотивационная сторона аудирования, чаще всего зависит от участников общения, исходя из чего аудирование получается «как бы производным, вторичным в коммуникативной деятельности» (там же: 83).

В своем исследовании Е. Н. Соловова определяет процесс аудирования, как восприятия и понимания речи на слух (Соловова, 2003: 124). Н.Д.Гальскова рассматривает в своем исследовании вопросы развития 
умений дистантного аудирования, который понимает, как «восприятие и понимание аудиотекстов в условиях опосредованного общения» (Гальскова, 2004: 175). Аудирование, полагает Н. И. Гез, представляет собой сложную рецептивную мыслительно-мнемическую деятельность, связанную с восприятием, пониманием и активной переработкой информации, которая содержится в устном речевом сообщении (Гальскова, Гез, 2004: 161).

Аудирование, как отмечает Е. Н. Соловова, представляет собой сложные виды речевой деятельности. Автор пишет, что в условиях реального общения аудирование характеризуется одноразовостью предъявления. Человек, как полагает Е. Н.Соловова, не в состоянии приспособить речь говорящего относительно своего уровня понимания и кроме того существуют объективные сложности, которые препятствуют осознанному пониманию ее с первого раза (Соловова, 2003: 125). Как отмечает автор, в процессе иноязычного аудирования можно выделить следующие трудности:

- трудности, обусловленные условиями аудирования: внешние шумы, помехи, плохая акустика;

- трудности, обусловленные индивидуальными особенностями источника речи, т. е. особенности дикции, тембра, темпа, паузации, возможными нарушениями артикуляции;

- трудности, обусловленные языковыми особенностями воспринимаемого материала, т. е. использование большого количества незнакомой лексики, идиоматических выражений, разговорных форм, специальных терминов, аббревиатур (Соловова, 2003: 125-127).

Наряду с трудностями при иноязычном аудировании, Е. Н. Соловова отмечает факторы успешности аудирования. Среди них ученый отдельно выделяет: речевой слух, память, вероятностное прогнозирование, артикулирование. Знание этих механизмов, считает ученый, необходимо для развития навыков аудирования у тех обучающихся, которые не владеют ими, и предлагает определить пути совершенствования данных навыков через решение системы упражнений и заданий (там же: 129-130).

Н. Д. Гальскова выделяет следующие факторы успешности аудирования:

- экстралингвистического характера. К ним можно отнести: скорость с какой воспроизводится аудиозапись; наличие опор, которые способствуют облегчению процесса восприятия и понимания вербальной информации;

- индивидуально-личностного характера. Основанного на речевом и языковом опыте обучающегося в родном и иностранных языках, а также уровня сформированности механизмов аудирования;

- лингвистического характера. Заключающиеся в языковой, структурной и содержательной характеристики текста (Гальскова, 2004: 175).

Для успешной организации процесса обучения аудированию, полага- 
ет Н. Д. Гальскова, необходимо принимать во внимание вышеназванные факторы. Автором также были выделены трудности аудирования заключающиеся в том, что факторы успешности аудирования определенным образом способствуют возникновению трудностей в овладении умениями слухового восприятия и понимания текстов и последовательности в построении системы обучения слуховой рецепции (там же: 176).

Раскрывая особенности обучения аудированию, Н. Д. Гальскова и Н. И. Гез отмечают то, что слушающий в процессе аудирования основывается на достаточно развитых психологических механизмах, и своем альтернативном опыте. Авторы полагают, что аудирование - это строго личностный процесс, сложный, зависящий следующих факторов: от развитости у учащегося речевого слуха и памяти; его умения использовать вероятностное прогнозирование, а также наличием у него внимания и интереса. Среди факторов успешности аудирования они выделяют:

- темп речевых сообщений, которые способствуют быстроте и точности понимания, а также эффективности запоминания;

- объем речевых сообщений, где первостепенное значение имеет решение вопроса необходимости повторного (многократного) предъявления одного и того же речевого сообщения, а также продолжительности его звучания;

- опоры и ориентиры восприятия в разных ситуациях речевого общения, где их характер изменяется исходя из речевого опыта и ситуации общения (Гальскова, Гез, 2004: 166-170).

На основании выделенных выше общекультурных компетенций, а также особенностей аудирования, нами были разработаны задания для обучения аудированию в трех языковых группах (низкого, среднего и высокого уровней подготовленности) студентов Московского колледжа управления, гостиничного бизнеса информационных технологий «Царицыно» разного уровня подготовленности. Исследование проводилось с сентября 2015 по май 2016. В нем приняло участие 36 студентов. В процессе реализации заданий нами были проведены констатирующие, формирующие и контрольные срезы.

Наглядно усредненные показатели результатов срезов в выделенных нами подгруппах можно увидеть в таблице. 
Таблица. Показатели результатов экспериментальных срезов в группах разного уровня подготовленности

\begin{tabular}{|l|c|c|c|}
\hline \multirow{2}{*}{ Группа } & \multicolumn{3}{|c|}{ Срезы } \\
\cline { 2 - 4 } & констатирующие & формирующие & контрольные \\
\hline $\begin{array}{l}\text { Низкий } \\
\text { уровень } \\
\text { подготовленности }\end{array}$ & $10,3 \%$ & $15,3 \%$ & $26,6 \%$ \\
\hline $\begin{array}{l}\text { Среднего } \\
\text { уровень } \\
\text { подготовленности }\end{array}$ & $31,5 \%$ & $41,5 \%$ & $49,3 \%$ \\
\hline $\begin{array}{l}\text { Высокого } \\
\text { уровень } \\
\text { подготовленности }\end{array}$ & $42,0 \%$ & $55,0 \%$ & $59,7 \%$ \\
\hline
\end{tabular}

Основываясь на результатах контрольного среза, приведенных в таблице, следует отметить, что у большинства респондентов, относящихся к каждой из выделенных нами групп, произошло улучшение показателей. Улучшение показателей результативности в группе с низким уровнем подготовленности составило $27 \%$; в группе средним уровнем подготовленности $-49 \%$; в группе с высоким уровнем подготовленности составил $60 \%$.

Более наглядно данные результаты представлены на рисунке.

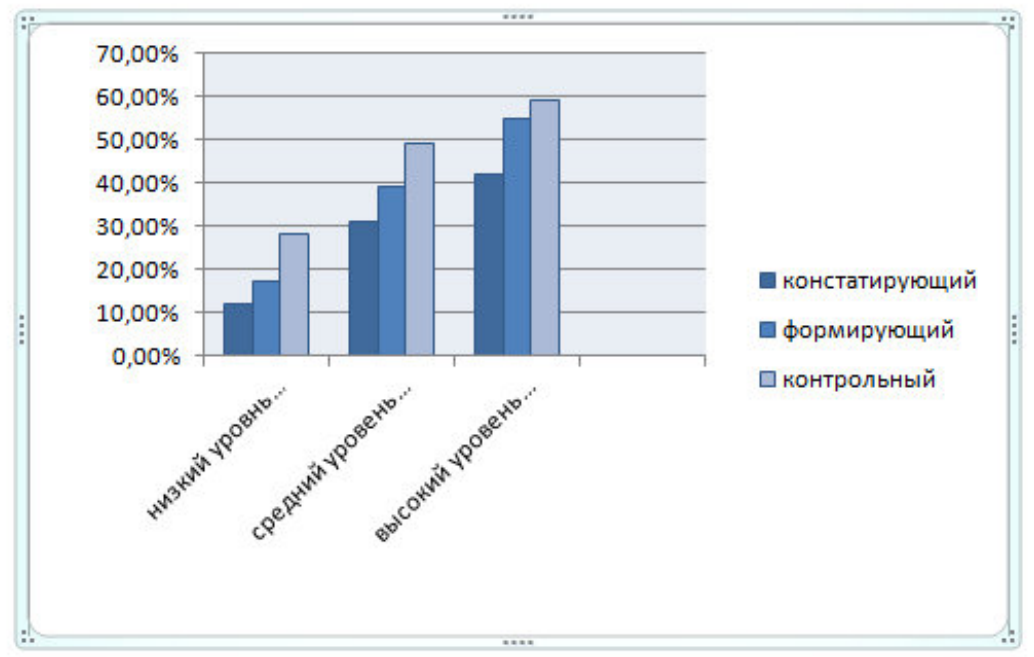

Рисунок. Результаты констатирующие, формирующие и контрольные срезы срезов в группах

Можно сделать вывод о эффективности обучения студентов СПО иностранному языку путем использования заданий в основе которых лежит метод аудирования. Исходя из анализа полученных нами результатов исследования, следует выделить улучшение показателей успеваемости учащихся СПО в трех языковых группах (низкого, среднего и высокого уровней подготовленности). На наш взгляд весьма показательными 
оказались результаты, которые продемонстрировали студенты среднего уровня подготовленности. В данной группе наблюдается наилучшая динамика улучшения результатов.

Подводя итог вышесказанному, следует отметить, что в силу нового социального заказа общества отмечается смещение акцента в целях обучения иностранному языку в сторону обучения устному общению учащихся СПО, процесс которого реализуется через аудирование.

\section{СПИСОК ЛИТЕРАТУРЫ}

Приказ Министерства образования и науки РФ от 7 мая 2014 г. N 474

«Об утверждении федерального государственного образовательного стандарта среднего профессионального образования по специальности 43.02.10 Туризм» [Электронный ресурс] // Гарант. URL: http://base.garant. ru/70683774/\#ixzz4d8eEnXuf (дата обращения: 22.02.2017).

Постановление Правительства РФ от 15 апреля 2014 г. N 295 «Об утверждении государственной программы Российской Федерации «Развитие образования» на 2013-2020 годы» [Электронный ресурс] // Гарант. URL: http://base.garant.ru/70643472/\#ixzz4d8dargc8 (дата обращения: 22.02.2017).

Федеральный закон Российской Федерации от 29 декабря 2012г. №273Ф3 «Об образовании в Российской Федерации» (утв. Государственной Думой 21декабря 2012 г., одобрен Советом Федерации 26 декабря 2012г.) [Электронная версия] // КонсультантПлюс. URL: http://www.consultant.ru/ document/cons_doc_LAW_140174/ (дата обращения: 22.02.2017).

Бриггс, Д. (2017) Python для детей. Самоучитель по программированию. Изд-во: Манн, Иванов и Фебер. 320 с.

Гальскова, Н. Д. (2004) Современная методика обучения иностранным языкам : пособие для учителя. М. : АРКТИ. 192 с.

Гальскова, Н. Д., Гез, Н. И. (2004) Теория обучения иностранным языкам: Лингводидактика методика : учеб. пособие для студ. лингв. ун-тов и фак. ин. яз. высш. пед. учеб. заведений. М. : Академия. 336 с.

Елухина, Н. В. (1996) Обучение слушанию иноязычной речи // Иностранные языки в школе. № 5. С. 20-32.

Жинкин, Н. И. (1982) Речь как проводник информации. М.: Наука. 159 с.

Зимняя, И. А. (2001) Лингвопсихология речевой деятельности. М. : Московский психолого-социальный институт ; Воронеж : НПО Модэк. 432 с.

Ильина, В. И. (1969) Аудирование // Материалы УШ и IX Международных методических семинаров преподавателей русского языка стран социализма. М. : Изд-во МГУ. С. 18-31.

Кочкина, 3. А. (1964) Аудирование: что это такое? // Иностранные языки в школе. № 5. С. 14-18. 
Соловова, Е. Н. (2003) Методика обучения иностранным языкам : базовый курс лекций : пособие для студентов пед. вузов и учителей. М. : Просвещение. 239 с.

Халеева, И. И. (1989) Основы теории обучения пониманию иноязычной речи (Подготовка переводчиков). М. : Высшая школа. 237 с.

Brown, J. S. (1988) Situated cognition and the culture of learning [Text] / J. S. Brown, A. Collins, P. Duguid. P. $32-42$.

Harmer, J. (2001) How to Teach English. An introduction to the practice of English language teaching. Pearson Education Limited. 198 p.

Richards, J. C. (2008) Teaching Listening and Speaking. From Theory to Practice. Cambridge University Press. 48 p.

White, G. (1998) Listening. Oxford University Press.154 p. Дата поступления: 12.03.2017 2.

Хатзипетру Ольга Сергеевна - преподаватель английского языка Московского колледжа управления, гостиничного бизнеса и информационных технологий «Царицыно». Адрес: 115551, Россия, г. Москва, Шипиловский пр., д. 37, корп. 1. Тел.: +7 (916) 062-24-23. Эл. адрес: Kondratova. olga.s@gmail.com

Hatzipetru Olga Sergeevna, Teacher of English, Moscow College of Administration, Hotel Business and Information Technologies "Tsaritsyno". Postal address: 37/1, Shipilovskiy Dr., Moscow, Russian Federation 115551. Tel.: +7 (916) 062-24-23. E-mail: Kondratova.olga.s@gmail.com

\section{Для цитирования:}

Хатзипетру О. С. Вопросы обучения иноязычному аудированию студентов среднего профессионального образования [Электронный ресурс] // Научные труды Московского гуманитарного университета. 2017, № 2. URL: http://journals.mosgu.ru/ trudy/article/view/453 (дата обращения: дд.мм.гг.). DOI: 10.17805/trudy.2017.2.7 